\title{
New Development Hunian Nelayan Kenjeran sebagai Kampung Wisata Nelayan
}

\author{
Rela Habibah dan Wahyu Setyawan \\ Departemen Arsitektur, Fakultas Teknik Sipil dan Perencanaan, Institut Teknologi Sepuluh Nopember (ITS) \\ e-mail:wahyu_s@arch.its.ac.id
}

\begin{abstract}
Abstrak-Permukiman pesisir terbentuk karena adanya aktivitas nelayan dalam memenuhi kebutuhan bertempat tinggal dan bermata pencaharian. Pemkot Surabaya kini menetapkan kawasan Kenjeran menjadi Kampung Wisata Bahari. Namun masih ada permasalahan pada kondisi fisik eksisting yang timbul seperti kualitas lingkungan dan kondisi hunian yang kurang ideal. Oleh karena itu, dibutuhkan pengembangan baru pemukiman dengan penataan yang dapat menunjang kualitas permukiman. Hal ini mengacu pada pengembangan pemukiman khas Indonesia yang disebut kampung tanpa memindahkan penghuni ke tempat yang baru. Kemudian menempatkan kembali penghuni asal tanpa merubah gaya hidup mereka yang lama dan kondisi fisik yang lebih baik dari yang lama. Konsep tersebut diwujudkan dalam obyek rancang berupa Kampung Wisata Nelayan, yaitu inovasi baru penataan landed housing yang mengaplikasikan kegiatan wisata kampung bahari dan memlibatkan penghuni dalam mengembangkan huniannya. Konsep hunian ini disebut pula dengan Elemental Housing.
\end{abstract}

Kata Kunci-Permukiman Nelayan, New Development, Kampung Wisata Nelayan.

\section{PENDAHULUAN}

$\mathrm{I}_{\mathrm{p}}^{\mathrm{su}}$ SU permukiman pesisir yang padat di kota besar menjadi populer dekade terakhir ini. Berbagai program pemerintah kota-kota di Indonesia mulai mengembangkan potensi daerah di pesisir termasuk pula pemukiman kampung nelayan. Namun kegiatan pengembangan yang dilaksanakan masih sebatas pembangunan fisik fasilitas pariwisata pesisir yang ada tanpa memperhatikan keberadaan kampung nelayan. Permukiman ini biasanya kurang memiliki fasilitas lingkungan yang ideal.

Pemkot Surabaya memiliki rencana untuk menghadirkan kampung nelayan di Kenjeran sebagai kampung wisata nelayan dan kaitannya dalam menjadikan kawasan pesisir timur Surabaya sebagai kawasan wisata bahari. Didukung pula dari RTRW Surabaya bahwa kawasan ini berada pada Unit Pembangunan 3 yang akan dikembangkan sebagai wilayah pemukiman, perdagangan, wisata, jasa dan konservasi. (Gambar 4)

Namun dengan beberapa fakta kondisi pada eksisting, bisa dikatakan bahwa kawasan Kampung Nelayan masih belum ideal. Beberapa hal-hal fisik seperti bangunan hunian, fasilitas publik, dan lingkungan menjadi pertimbangannya. (Gambar 1)

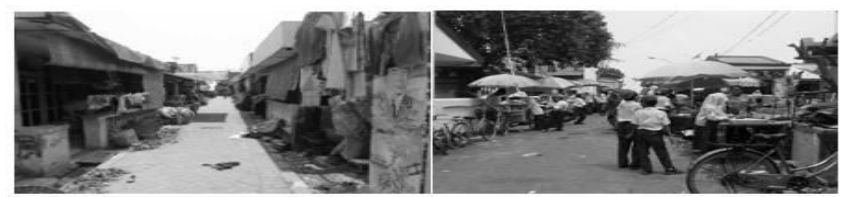

Gambar 1. Kondisi Eksisting Kampung Nelayan Kenjeran Sumber: Dokumentasi Pribadi
New development pemukiman menurut Prof. Danisworo adalah sebuah penataan kawasan dengan cara mengganti sebagian atau seluruh unsur-unsur lama dari kawasan tersebut dengan unsur-unsur yang baru untuk meningkatkan vitalitas serta kualitas dari lingkungan suatu kawasan tersebut tanpa memindahkan penghuni dari tempat asalnya. Penataan kembali suatu kawasan terlebih dahulu dilakukan pembongkaran sarana dan prasarana yang tidak dapat dipertahankan lagi [1].

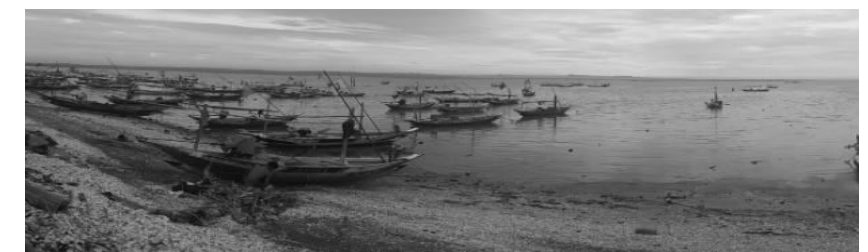

Gambar 2 .Kondisi Gang pada Kampung Nelayan.

Sumber: Dokumentasi Pribadi

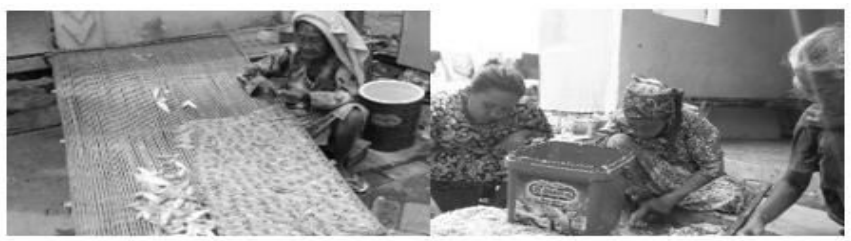

Gambar 3. Aktivitas Masyarakat Kampung Nelayan.

Sumber: Dokumentasi Pribadi

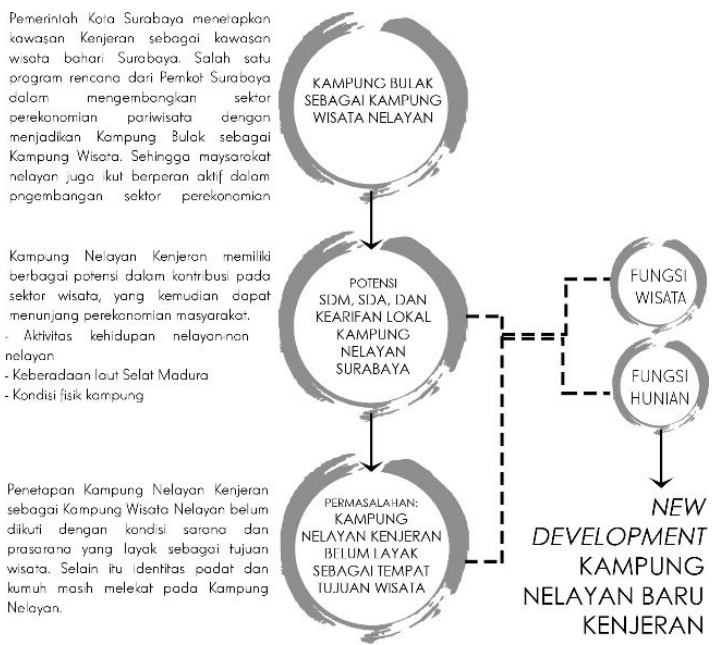

Gambar 4. Diagram Isu.

Sumber: Dokumentasi Pribadi

Pengembangan baru permukiman kampung ini diwujudkan dalam bentuk obyek rancangan berupa kampung wisata nelayan yaitu pemukiman hunian landed yang menambahkan fungsi wisata sebagai upaya pengingkatan perekonomian. Rancangan ini tetap mempertahankan karakter khas kampung 
baik secara fisik maupun non fisik. Karakter kampung seperti gang yang sempit (gambar 2) dan non fisik berupa interaksi antar warga yang heterogen di dalam gang tersebut (gambar 3). Pertimbangan lain mengenai aktivitas pekerjaan mereka sebagai nelayan yang tidak dapat jauh dari tempat tinggal. (gambar 5)

Penataan permukiman ini menjadi salah satu wadah atraksi wisata kampung yang memenuhi kebutuhan penyediaan bagi wisatawan lokal/non lokal dan penduduk kampung nelayan sehingga layak untuk dijadikan sebagai tempat bermukim dan destinasi wisata aktivitas kampung pesisir Kota Surabaya. (gambar suasana dermaga)

\section{EKSPLORASI DAN PROSES RANCANG}

\section{A. Pendekatan dan Metode Desain}

Pendekatan yang digunakan pada proses rancangan menggunakan Community Based Design. Pendekatan ini merupakan aktivitas desain non-individualistik, nonkompetitif, yang langsung terlibat dengan klien dan pengguna dalam proses pengambilan keputusan. Proses pendekatan ini membuat perancang lebih peka untuk mencerna isu dan mencari alternatif-altenatif yang sesuai dengan kehidupan nyata sehingga pada tahap akhir yaitu pelaksanaan dapat sesuai dengan kebutuhan [2]. (Gambar 6)

Metode pemrograman arsitektur yang dipakai pada rancangan nantinya didasari oleh metode "Architecture Programming" dari Donna P. Duerk. Metode ini berbasiskan pada pokok isu. Permasalahan kemudian dianalisis menurut isu-isu tertentu, untuk selanjutkan diproyeksikan ke dalam beberapa tujuan, kriteria perancangan dan konsep perancangan.

\section{B. Konsep Desain}

Menurut Turner, pengembangan permukiman dibutuhkan peran penghuni dalam kelangsungan hidup sosial masyarakat. Namun permukiman justru dapat membatasi manusia karena beban biaya pada permukiman mereka. Dan segala hal mengenai pengembangan permukiman lebih kearah mewujudkan permukiman yang layak untuk seluruh lapisan masyarakat tanpa melibatkan manusia yang tinggal di dalamnya [3].

Keterlibatan manusia yang menempati sebuah permukiman atau rumah dalam mengembangkan rumahnya sendiri pada awalnya akan terlihat kurang rapi, namun nantinya dengan seiring berjalannya waktu mereka akan memperbaiki rumah mereka sesuai dengan kondisi ekonomi mereka. Turner menyebutnya dengan konsep housing as a process (perumahan sebuah proses) dan progressive development (pembangunan berkemajuan). Sejalan dengan pemikiran dari John F.C. Turner ini, Johan Silas (1983) menjelaskan bahwa rumah sebagai suatu proses adalah mengembangkan rumah sesuai kehendak, kemampuan dan peluang yang ada pada setiap saat dan sejalan dengan proses pertumbuhan/perkembangan biologis, sosial, dan ekonomi keluarga yang bersangkutan [4].

Dalam proses pengembangan ini, dibutuhkan dua hal yaitu dengan menciptakan lingkungan yang mendukung penggunaan sumber daya setempat dan peran pemerintah untuk melindungi dan menyediakan sumber daya yang sulit diperoleh seperti memperbaiki layanan dasar yang akan mendorong tersedianya rumah.

Ada tiga poin dasar yang diimplementasikan pada rancangan Kampung Wisata Nelayan yaitu: fleksibilitas, lokalitas, dan ekonomis.

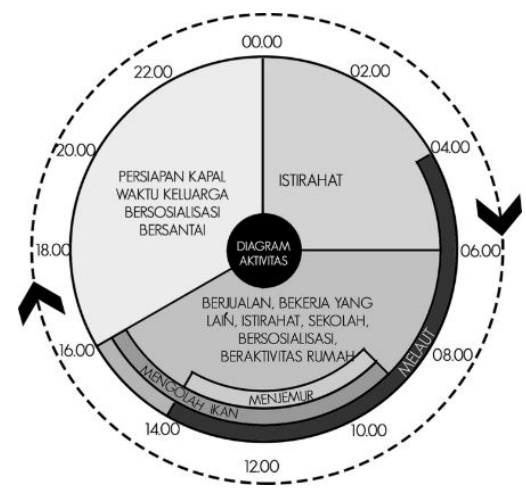

Gambar 5. Diagram Aktivitas Kampung Nelayan Kenjeran. Sumber: Dokumentasi Pribadi

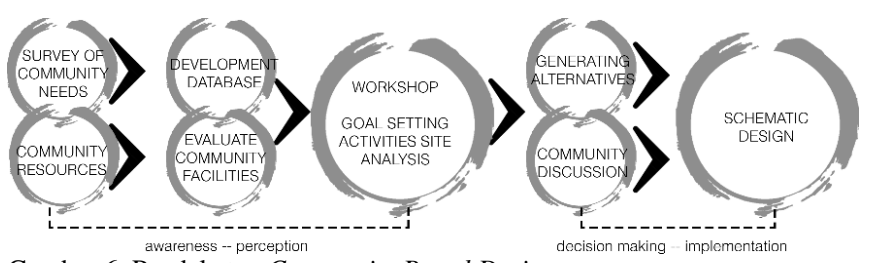

Gambar 6. Pendekatan Community Based Design.

Sumber: Salama, Ashraf. Spatial Design Education. 2015. Ashgate Publishing Company

\section{Konsep Penataan Tapak}

Konsep penatanan massa terbagi menjadi lima zona: zona hunian, zona fasilitas penunjang wisata, zona RTH, zona dermaga, zona fasilitas penunjang pemukiman. Pertimbangan perletakan disesuaikan dengan konsep sirkulasi, konsep privasi, konsep suasana, dll. (gambar 7)

Pola penataan hunian menggunakan pola cluster heterogen yang linier mengarah ke laut. Pola ini dipilih dengan pertimbangan jalur sirkulasi dan jalur evakuasi. (gambar 7)

\section{Konsep Hunian}

Konsep hunian Elemental Housing mengacu pada teori Turner "Housing by People" and "Housing as a Process". Konsep fasad hunian didasarkan atas aktivitas penghuni. Hunian dibagi menjadi tiga tipe. Tipe A dan tipe B adalah hunian untuk nelayan dengan spresifikasi jumlah penghuni pada tipe $\mathrm{A}$ adalahah 3 orang, sedangkan tipe $\mathrm{B}$ adalah 5 orang. Kemudian tipe $\mathrm{C}$ adalah hunian untuk non-nelayan dengan jumlah penghuni 3-5 orang. Konsep hunian ini juga menerapkan fleksibilitas pada ruang dalam hunian yang terletak pada ruang mezanin di tiap tipe dan ruang lantai bawah pada tipe A dan B (gambar 9) (gambar 11c). Pada area mezanin juga bertujuan mengefesiensikan ruang pada lahan yang sempit, salah satu fungsinya dapat dijadikan sebagai area istirahat atau tidur (gambar

Lantai bawah ini difungsikan untuk proses pengolahan ikan dan diberi batasan sekat void yaitu menggunakan roster dan bambu (gambar 10). Hal ini bertujuan untuk memudahkan jalur sirkulasi angin atau cahaya pada hunian. Selain itu pada area bawah hunian nelayan (tipe A dan tipe B) ini terdapat 
area bersama yang terletak di antara dua hunian, yang dapat difungsikan sebagai area interaksi sosial dan juga area membersihkan ikan, pengolahan ikan, serta penjemuran ikan kering (gambar 10) (gambar 11a).

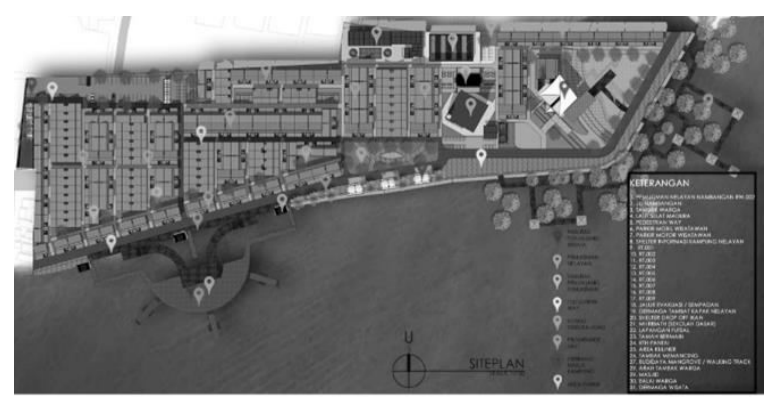

Gambar 7. Siteplan.

Sumber: Dokumentasi Pribadi

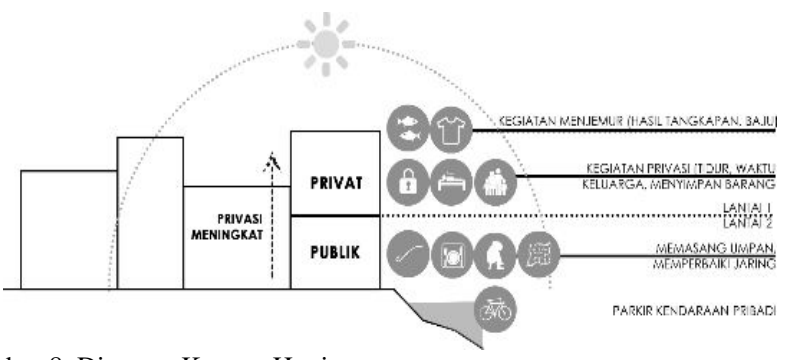

Gambar 8. Diagram Konsep Hunian.

Sumber: Dokumentasi Pribadi

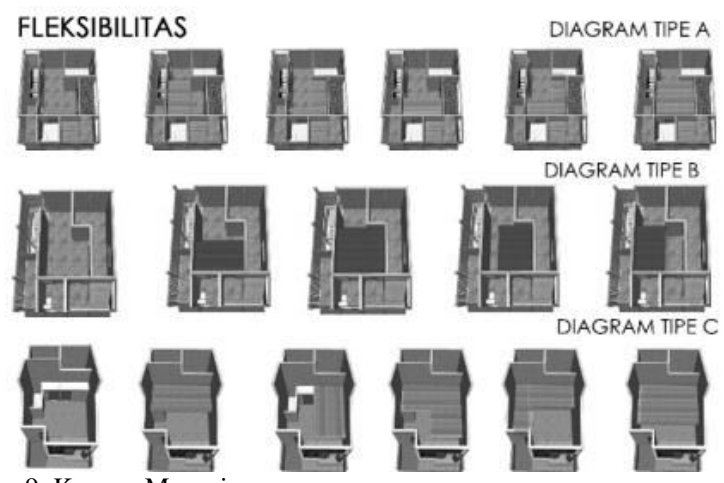

Gambar 9. Konsep Mezanin.

Sumber: Dokumentasi Pribadi

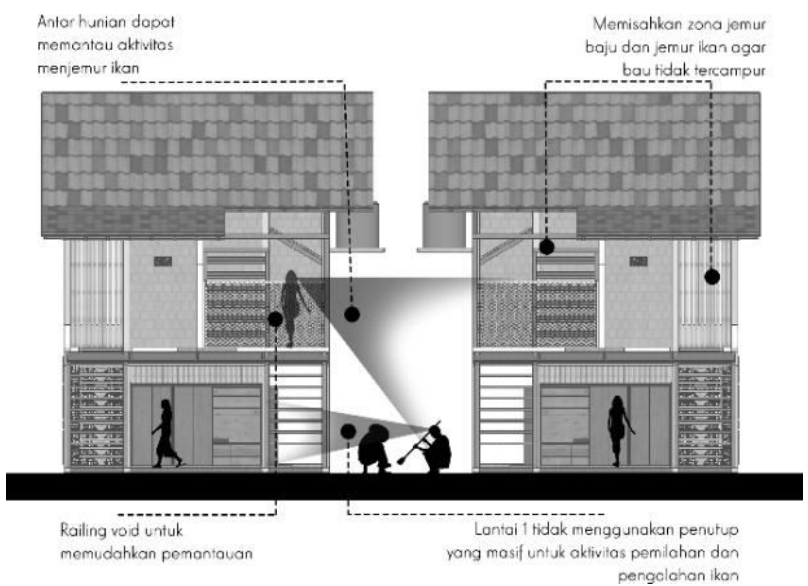

Gambar 10. Konsep Hunian.

Sumber: Dokumentasi Pribadi
Pada massa bangunan di kampung wisata nelayan menggunakan beberapa jenis material yang hampir sama dimana material unfinished diekspose dengan tujuan estetika dan keekonomisan. Hal injuga mendukung bentuk massa yang memberi kesan lokalitas dan vernakular kampung. (gambar 10) (gambar 11) (gambar12)

\section{HASIL RANCANGAN}

Desain hunian pada permukiman kampung nelayan Kenjeran berdasarkan aktivitas keseharian warga dan disinergikan dengan aktivitas dari wisatawan.
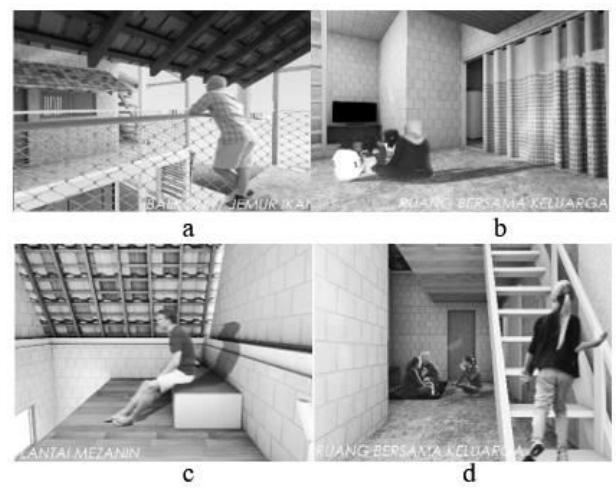

Gambar 11. Interior Hunian.

Sumber: Dokumentasi Pribadi

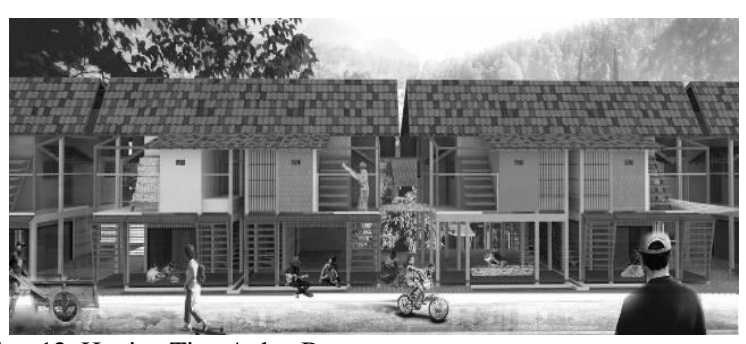

Gambar 12. Hunian Tipe A dan B.

Sumber: Dokumentasi Pribadi

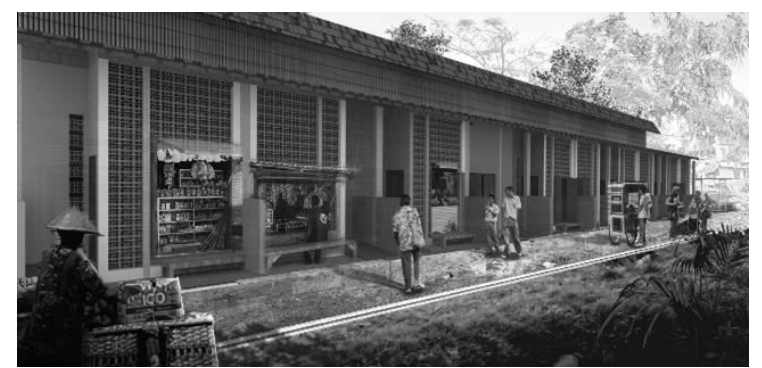

Gambar 13. Hunian Tipe C.

Sumber: Dokumentasi Pribadi

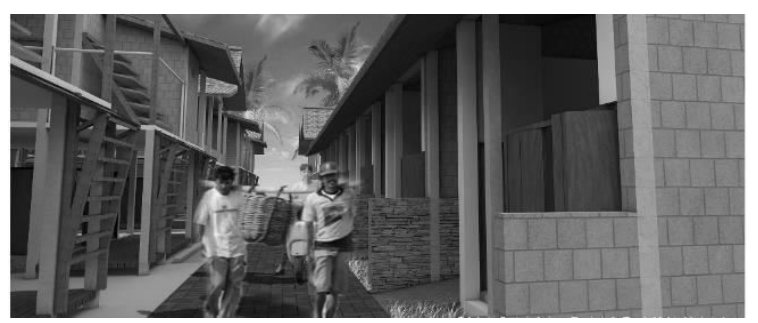

Gambar 14. Hunian Tipe C.

Sumber: Dokumentasi Pribadi 


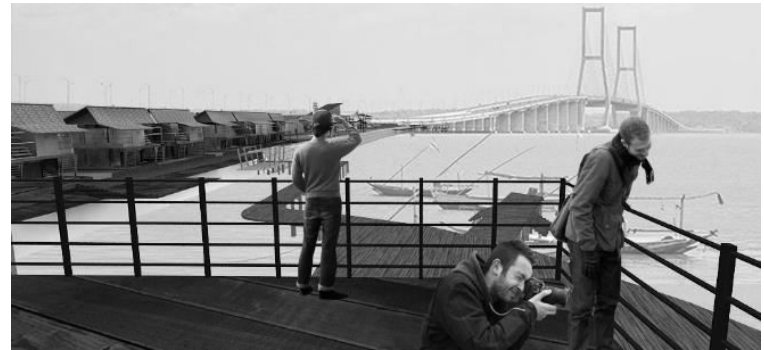

Gambar 15. Suasana Dermaga.

Sumber: Dokumentasi Pribadi

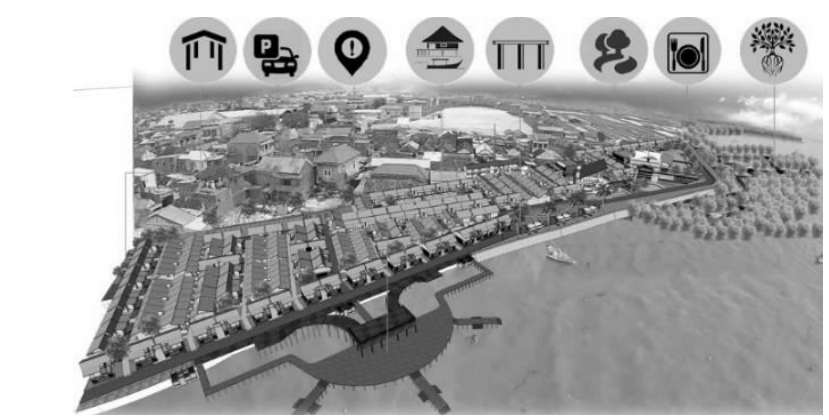

Gambar 16. Program Ruang Tapak.

Sumber: Dokumentasi Pribadi

\section{KESIMPULAN}

Keberadaan permukiman kumuh memberi image negatif tehadap tata ruang kota. Dampak yang dapat dilihat berupa penurunan kualitas lingkungan itu sendiri. Masalah mulai dari ruang terbuka hijau, drainase yang memburuk, dan kualitas infrastruktur. Berbagai program pemerintah direncanakan agar permukiman kumuh ini dapat dikatakan layak dan memberi pengaruh pada perekonomian. Berbagai potensi yang dapat dikembangkan dari pemukiman kumuh ini mampu menjadikan sebuah ikon baru.
Istilah relokasi justru dapat membatasi pengembangan SDM itu sendiri. Maka dari itu, dibutuhkan pemahaman bahwa permukiman kumuh sebagai salah satu bagian dari unsur perkotaan. Konsep new development memberikan strategi yang berbeda dimana suatu penataan sebuah kawasan dengan cara mengganti sebagian atau seluruh unsur-unsur lama dari kawasan tersebut dengan unsur-unsur yang baru dengan tujuan untuk meningkatkan vitalitas serta kualitas dari lingkungan suatu kawasan tersebut. Penataan kembali sesuatu kawasan terlebih dahulu dilakukan pembongkaran sarana dan prasarana yang tidak dapat dipertahankan lagi.

Penerapan strategi ini pada permukiman nelayan diwujudkan dalam bentuk oyek rancang berupa Kampung Wisata Nelayan yang selaran dengan rencana dari Pemkot Surabaya. Penataan kembali kawasan permukiman menjadi kawasan permukiman yang baru tidak merubah image non fisik yang telah ada. Adanya gang-gang sempit ini masih dipertahankan sebagai interaksi sosial antarwarga. Dengan mempertahankan karakter sosial yang kuat dan karakter warga nelayan yang sederhana, diharapkan penataan kembali permukiman memberikan kesempatan warga dalam bermukim dan mencari nafkah.

\section{DAFTAR PUSTAKA}

[1] Sihono, "Peran Serta Masyarakat Dalam Pengelolaan Prasarana Pasca Peremajaan Lingkungan Permukiman Di Mojosongo Surakarta," Universitas Diponegoro, 2003.

[2] A. Salama, Spatial Design Education. Ashgate Publishing Company, 2015.

[3] R. Ismariandi, P. Setijanti, and G. Ariastita, "Konsep Pengembangan Kampung Nelayan Pasar Bengkulu Sebagai Kawasan Wisata," in Seminar Nasional Perumahan Permukiman dalam Pembangunan Kota, 2010, no. 2.

[4] J. Silas, "Perumahan: masalah, potensi, konsep," Surabaya. 